\title{
Geochemical mass flux and fluid- rock interactions within the hydrothermal system of Surtsey, Iceland
}

S. PraUSE*1,4, T.B. WeISENBERGER ${ }^{1}$, P. SChIFFMAN ${ }^{2}$, P. CAPPELletTI ${ }^{3}$ AND M.T. GUdMUNDSSON ${ }^{4}$

${ }^{1}$ Iceland GeoSurvey, Reykjavík, Iceland (*correspondence: simon.prause@isor.is)

${ }^{2}$ University of California, Davis, USA

${ }^{3}$ University of Naples Federico II, Naples, Italy

${ }^{4}$ University of Iceland, Reykjavík, Iceland

Surtsey, a young oceanic island $33 \mathrm{~km}$ off Iceland's southern coast, formed between 1963-67 as the result of early stage phreatomagmatic and mid to late stage effusive volcanism. One year after the cessation of the eruptions the first signs for incipient hydrothermal circulation within the island's alkali basaltic tephra deposits were detected. An expedition was dispatched in 1979 which recovered a $181 \mathrm{~m}$ long drill core, SE-01, from the tephra deposits of Surtsey's southeastern vent Surtur. In 2017, a second drilling expedition was launched within the framework of the Surtsey underwater volcanic System for Thermophiles Alteration Processes and INovative concretes project (SUSTAIN) of the International Continental Scientific Drilling Program (ICDP) [1]. This new expedition recovered two new vertical drill cores, SE-02a and SE-02b, which were drilled to a measured vertical depth of 152 and $192 \mathrm{~m}$ below surface, respectively, with a $<10 \mathrm{~m}$ horizontal offset to SE-01 [2]. Additionally, core from one inclined drill hole, SE-03, aimed at the center of the Surtur vent at an angle of $55^{\circ}$ reaching $354 \mathrm{~m}$ measured depth, was also recovered.

These new drill cores present an unprecedented opportunity to study geochemical fluid-rock interactions and elemental fluxes associated with palagonitization of the island's glassy tephra deposits from a unique time-integrated perspective. Specifically, comparative geochemical analysis of samples from SE-01 and SE-02b allows us to gain an improved understanding into the elemental mass changes associated with the process of palagonitization of basaltic glass in a meteoric to seawater dominated hydrothermal environment and the development of authigenic mineral assemblages as a function of time, depth and temperature. These insights in turn have wider implications on global element mass fluxes.

[1] Jackson et al. (2019), Sci. Drill. 25, 35-46. [2] Weisenberger et al. (2019), ICDP Operational Report. 